\title{
Cost-effectiveness analysis of initial HIV treatment under Italian guidelines
}

This article was published in the following Dove Press journal:

ClinicoEconomics and Outcomes Research

28 October 201I

Number of times this article has been viewed

\section{Giorgio L Colombo ${ }^{1,2}$ \\ Vincenzo Colangeli ${ }^{3}$ \\ Antonio Di Biagio ${ }^{4}$ \\ Sergio Di Matteo ${ }^{2}$ \\ Claudio Viscoli ${ }^{4}$ \\ Pierluigi Viale ${ }^{3}$}

'School of Pharmacy, University of Pavia, Pavia, Italy; ${ }^{2}$ SAVE - Studi Analisi Valutazioni Economiche, Milan, Italy; ${ }^{3}$ Clinica Malattie Infettive, Azienda Ospedaliera Sant'Orsola Malpighi Bologna, Alma Mater Studiorum, University of Bologna, Bologna, Italy; ${ }^{4}$ Clinica Malattie Infettive dell'Ospedale San Martino di Genova, University of Genova, Genova, Italy
Correspondence: Giorgio L Colombo SAVE - Studi Analisi Valutazioni

Economiche, Via Previati, 74 - 20149

Milan, Italy

Tel +390248519231

Fax +390273960369

Email giorgio.colombo@savestudi.it
Introduction: Since the mid-1990s, highly active antiretroviral therapy (HAART) has modified the clinical course of human immunodeficiency virus (HIV) infection, reducing the rate of disease progression, the incidence of opportunistic infections, and mortality. The authors of this paper performed an economic analysis to estimate the cost-effectiveness of the HAART regimens in Italy for managing HIV-infected patients according to national guidelines.

Patients and methods: The incremental cost-effectiveness analysis was carried out by means of a Markov model, which through a decision-analytic approach, made it possible to compare the studied antiretroviral regimens. The population considered in the model consisted of adult subjects with HIV who received antiretroviral HAART treatment for the first time. The population considered in the analysis reflects the patients' characteristics according to one of the regional surveillance systems HIV/AIDS infection report currently operating in Italy. The analysis was carried out from the point of view of the Italian health care system. The considered outcome measures were quality-adjusted life years (QALYs) and direct health costs calculated for the year 2010. Both the outcomes (QALYs) and the costs were discounted by $3.5 \%$. The time horizon adopted in the model was 10 years.

Results: The model shows, in terms of cost per gained QALY, single tablet regimen (STR) appeared to be the most cost-effective therapeutic choice $(€ 22,017)$, followed by tenofovir (TDF) + lamivudine + efavirenz (EFV) $(€ 24,526)$, and TDF/emtricitabine (FTC) + nevirapine $(€ 26,416)$, and TDF + FTC + EFV (€26,558); the remaining strategies have an incremental costeffectiveness ratio (ICER) value varying from $€ 28,000$ to $€ 41,000$ per QALY. The sensitivity analysis on the main variables confirmed the validity of the base case scenario.

Conclusion: STR is the most cost-effective treatment strategy, compared with the other therapeutic regimens recommended by the Italian guidelines. All the ICER values of the various regimens considered by the Italian guidelines were lower than the threshold value of $€ 50,000$ commonly accepted at the international level. The model developed represents a tool for policy makers and health care professionals to make short- and long-term cost projections and thus evaluate their impact on the available budgets for HIV patients.

Keywords: antiretroviral therapy regimens, single tablet regimens, STR, Markov model, quality-adjusted life years, QALYs, HAART

\section{Introduction}

According to UNAIDS, at the end of 2009, 33.3 million people worldwide were estimated to be living with human immunodeficiency virus (HIV) or acquired immunodeficiency syndrome (AIDS). ${ }^{1}$ In Italy, the surveillance of HIV/AIDS in the period 1985-2008 reported a total of 42,747 new HIV diagnoses. In 2007, there were 2012 new HIV diagnoses, equivalent to an incidence of 6.7 per 100,000 residents. ${ }^{2}$ 
The economic burden of HIV infection is well recognized all around the world. ${ }^{3,4}$ Its management involves the use of health care service for HIV treatment, the treatment of AIDS-associated symptoms and opportunistic infections, and other costs associated with morbidity/premature mortality of adult working patients. Since the mid-1990s, highly active antiretroviral therapy (HAART) has modified the clinical course of the HIV infection, reducing the rate of disease progression, the incidence of opportunistic infections, and mortality. ${ }^{5,6}$ This prolonged survival has changed HIV infection into a chronic disease. ${ }^{7}$ As a consequence, combination antiretroviral therapy has resulted in longer survival and a better quality of life for many HIV-infected patients. ${ }^{8}$ The current therapeutic options available in Italy and Europe include more than 20 approved antiretroviral drugs divided into five classes: nucleoside/nucleotide reverse transcriptase inhibitors (NRTIs), non-nucleoside reverse transcriptase inhibitors (NNRTIs), protease inhibitors, fusion or entry inhibitors, and integrase inhibitors (InI). Each of these groups attacks HIV in a different way. The most common drug regimen (as HAART) given to people beginning treatment usually consists of two NRTIs combined with either an NNRTI, or a "boosted" protease inhibitor, or an InI. ${ }^{9}$ Each drug varies greatly in terms of efficacy, resistance, pill burden, safety, and price. Considering the complexity of the disease, the Italian recommendations are invaluable in assisting physicians in electing the most favorable therapies. However, because HIV is a prolonged disease, the treatment of which may continue for many years, the need for regimens with potent antiviral activity, proven long-term safety, good adherence, and a low rate of antiviral resistance should also be evaluated in terms of lifetime costs. In a context of limited health care resources, pharmacoeconomic considerations are crucial to help policy makers make the most appropriate decisions on resource allocation. The authors of this paper therefore performed an economic analysis to estimate the cost-effectiveness of the HAART regimens in Italy for managing HIV-infected patients according to national guidelines. ${ }^{9}$ They also estimated the impact of the disease on the quality of life of patients.

\section{Patients and methods}

The purpose of this study was to determine the incremental cost-effectiveness ratio (ICER) per (quality-adjusted) year of life gained for therapeutic combinations (regimens) based on drugs recommended by the Italian guidelines for the firstline treatment of patients with HIV. ${ }^{9}$ The incremental costeffectiveness analysis was carried out by means of a Markov model, which through a decision-analytic approach, made it possible to compare the studied antiretroviral regimens. ${ }^{10}$ The analysis was carried out from the point of view of the Italian health care service (Servizio Sanitario Nazionale [SSN]). The considered outcome measures were quality-adjusted life years (QALYs) and direct health costs calculated for the year 2011. Both the outcomes (QALYs) and the costs were discounted by $3.5 \% .{ }^{11}$ The time horizon adopted in the model was 10 years. The antiretroviral regimens considered follow the latest Italian guidelines and represent the drug options that are more frequently used in the first-line treatment of patients with HIV. ${ }^{9}$ The population considered in the model consisted of adult subjects with HIV who received antiretroviral HAART treatment for the first time; this hypothetical cohort reflects the patient characteristics according to one of the regional surveillance systems HIV/AIDS infection report currently operating in Italy. ${ }^{12}$

\section{Structure of the model}

The Markov model simulates the quality of life and the costs for an HIV patient for 10 years, starting from the administration of the initial treatment, through 1-year cycles, based on the administered antiretroviral therapy. ${ }^{13}$ After entering the model and receiving one of the antiretroviral regimens, the patient can "move" through eight health states, defined by the CD4-cell count combined with the viremia levels (VL), one AIDS state and one death state (Figure 1).

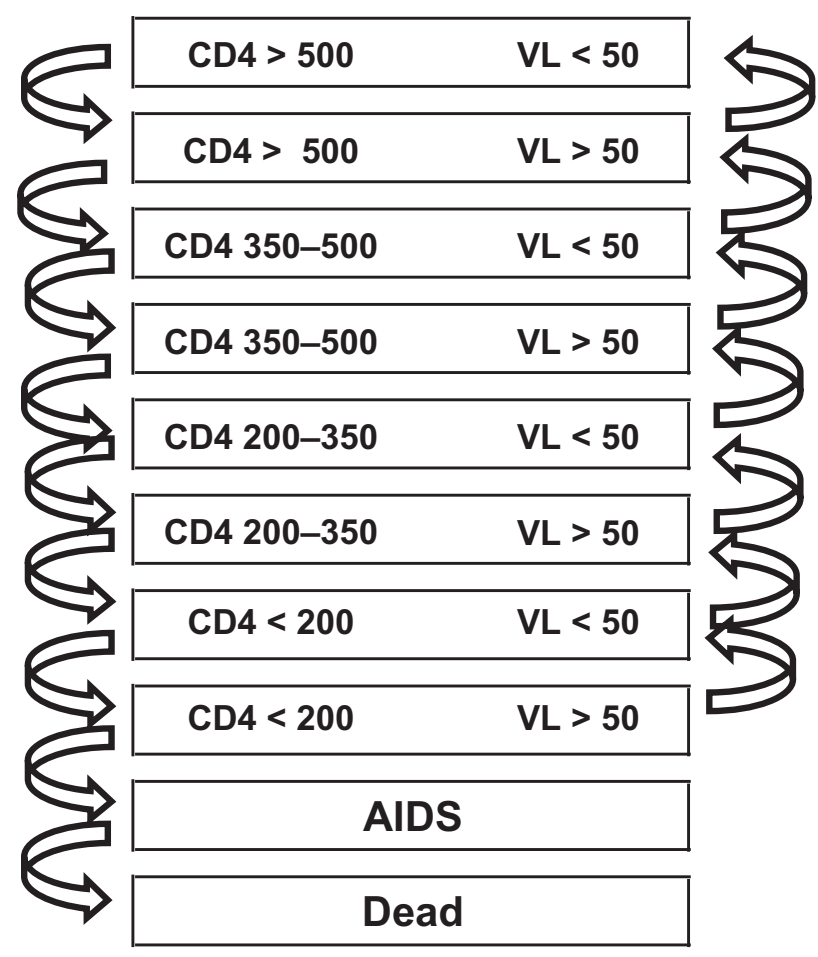

Figure I Structure of the Markov model.

Abbreviations: AIDS, acquired immunodeficiency syndrome; VL, viremia levels. 
The model assigned patients responding to the antiretroviral therapy a viremia value lower than 50 copies, and allowed responders to move within the $\mathrm{CD} 4$ classification. In case of failure of the first-line treatment, the model presumed a viremia value $>50$ copies for the patients and CD4 values following the trend of the untreated population. ${ }^{14}$ Nonresponders with a CD4 value $<200$ were changed to the AIDS state; patients were changed to the death state depending on their CD4 class, as shown in Table 1, and also $25 \%$ of patients with full-blown AIDS. ${ }^{2}$ Finally, the model was completed with appropriate occurrence values to define probabilistic knots, and with precise cost estimates, in order to finalize the comparison, as described below. Modeling was undertaken using Microsoft Excel 2010 (Microsoft Corporation, Redmond, WA).

\section{Transition probabilities and outcomes}

Tables 1 and 2 report the percentage distribution of patients considered in the model with respect to the CD4-cell count. The distribution draws on the observations on the HIV-AIDS infection situation in the Emilia Romagna region (epidemic update as of December 31, 2009). Table 3 shows the immunologic responses for each of the therapeutic regimens studied, as indicated in the Italian guidelines, and reports the bibliographical references. When data were not available, it was assumed that the response remained constant at the last observed value by applying the last value carried forward technique.

To evaluate cost-effectiveness, the ICER was used. When the value of a new therapeutic option needs to be assessed, the ICER provides the additional resources that have to be used to achieve the additional benefit: ICER is the difference in cost divided by the difference in effect between two alternatives. In this analysis, the direct costs and effectiveness of each regimen were compared with the direct costs

Table I Patient distribution based on CD4-cell count and viremia and mortality per health state ${ }^{13}$

\begin{tabular}{lll}
\hline CD4-cell count & $\begin{array}{c}\text { Viremia } \\
(\mathbf{V L})\end{array}$ & $\begin{array}{l}\text { HIV-linked } \\
\text { mortality rate }\end{array}$ \\
\hline$>500$ cells $/ \mu \mathrm{L}$ & $<50$ & $0.40 \%$ \\
$>500$ cells $/ \mu \mathrm{L}$ & $\geq 50$ & $0.40 \%$ \\
$35 \mathrm{I}-500$ cells $/ \mu \mathrm{L}$ & $<50$ & $0.40 \%$ \\
$35 \mathrm{I}-500$ cells $/ \mu \mathrm{L}$ & $\geq 50$ & $0.40 \%$ \\
$20 \mathrm{I}-350$ cells $/ \mu \mathrm{L}$ & $<50$ & $0.80 \%$ \\
$20 \mathrm{I}-350$ cells $/ \mu \mathrm{L}$ & $\geq 50$ & $0.80 \%$ \\
$<200$ cells $/ \mu \mathrm{L}$ & $<50$ & $8.44 \%$ \\
$<200$ cells $/ \mu \mathrm{L}$ & $\geq 50$ & $8.44 \%$ \\
\hline
\end{tabular}

Abbreviation: HIV, human immunodeficiency virus.
Table 2 Patient distribution based on CD4-cell count and viremia

\begin{tabular}{|c|c|c|c|}
\hline CD4-cell count & $\begin{array}{c}\text { Viremia } \\
\text { (VL) }\end{array}$ & $\begin{array}{l}\% \text { distribution } \\
\text { of patients }^{a} \\
\text { (base case) }\end{array}$ & $\begin{array}{l}\text { \% distribution } \\
\text { of patients } \\
\text { (sensitivity } \\
\text { analysis) }\end{array}$ \\
\hline$>500$ cells $/ \mu \mathrm{L}$ & $<50$ & $12.98 \%$ & $3.25 \%$ \\
\hline$>500$ cells $/ \mu \mathrm{L}$ & $\geq 50$ & $12.98 \%$ & $3.25 \%$ \\
\hline $35 \mathrm{I}-500$ cells $/ \mu \mathrm{L}$ & $<50$ & $12.98 \%$ & $7.00 \%$ \\
\hline $35 \mathrm{I}-500$ cells $/ \mu \mathrm{L}$ & $\geq 50$ & $12.98 \%$ & $7.00 \%$ \\
\hline $20 \mathrm{I}-350$ cells $/ \mu \mathrm{L}$ & $<50$ & $16.36 \%$ & $18.75 \%$ \\
\hline $20 \mathrm{I}-350$ cells $/ \mu \mathrm{L}$ & $\geq 50$ & $16.36 \%$ & $18.75 \%$ \\
\hline$<200$ cells $/ \mu \mathrm{L}$ & $<50$ & $7.70 \%$ & $21.00 \%$ \\
\hline$<200$ cells $/ \mu \mathrm{L}$ & $\geq 50$ & $7.70 \%$ & $21.00 \%$ \\
\hline
\end{tabular}

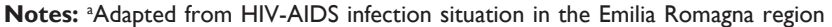
(epidemic update as of December 31, 2009) ${ }^{12}$; badapted from Gallant et al. ${ }^{15}$

and effectiveness of the disease natural history (absence of treatment).

The effectiveness indicators considered in this economic evaluation are the QALYs. Table 4 shows the utility values associated with the eight health states identified by the CD4-cell count. These values, published in the study by Simpson et al, ${ }^{13}$ were calculated by means of the EuroQol-5 Dimensions (EQ-5D) questionnaire. ${ }^{29}$ The permanence in the disease state (CD4 and viremia) was adjusted for the corresponding utility and then combined for the average expected lifetime, with the purpose to evaluate the years of survival adjusted for the quality of life. ${ }^{30}$

\section{Resource consumption and costs}

The resource consumption associated with the patients considered in the model is linked with the administration of the antiretroviral regimens and with other direct health costs, such as hospitalizations, medical examinations, laboratory tests, and so on. Table 5 shows the average annual costs for each first-line regimen. Dosages were calculated based on the Italian and British guidelines; ${ }^{9,31}$ whereas the purchase costs of the pharmaceutical specialties were calculated based on the reimbursement price paid by the SSN, which takes into account the price updates effective from January $1,2011.32$

For every health state defined by the CD4-cell count, an additional health cost associated with patients was assumed, including a further consumption of health resources due to hospitalization, day hospital, general practitioner and specialist examinations, laboratory tests, and diagnostic procedures. Costs were estimated based on the results of the research by Garattini et $\mathrm{al}^{33}$ (Table 6). The cost data stratified by CD4 were then actualized to $2010.34,35$ 
Table 3 Efficacy data: immunologic response per different treatment regimen

\begin{tabular}{|c|c|c|c|c|c|c|c|c|c|c|c|c|}
\hline & \multirow[t]{3}{*}{ Treatment } & \multicolumn{10}{|c|}{ Response rate } & \multirow[t]{3}{*}{ Source } \\
\hline & & \multicolumn{10}{|l|}{ Year } & \\
\hline & & I & 2 & 3 & 4 & 5 & 6 & 7 & 8 & 9 & 10 & \\
\hline Atripla & $\begin{array}{l}\text { TDF/FTC + EFV } \\
\text { (single tablet } \\
\text { regimen) }\end{array}$ & $80.00 \%$ & $67.00 \%$ & $64.00 \%$ & $64.00 \%$ & $64.00 \%$ & $64.00 \%$ & $64.00 \%$ & $64.00 \%$ & $64.00 \%$ & $64.00 \%$ & $\begin{array}{l}\text { Gallant et al, }{ }^{15} \\
\text { Pozniak et al, }{ }^{16} \\
\text { Arribas et al }{ }^{17}\end{array}$ \\
\hline $\begin{array}{l}\text { Truvada }+ \\
\text { Sustiva }\end{array}$ & TDF/FTC + EFV & $80.00 \%$ & $67.00 \%$ & $64.00 \%$ & $64.00 \%$ & $64.00 \%$ & $64.00 \%$ & $64.00 \%$ & $64.00 \%$ & $64.00 \%$ & $64.00 \%$ & $\begin{array}{l}\text { Gallant et al, }{ }^{15} \\
\text { Pozniak et al, }{ }^{16} \\
\text { Arribas et al }{ }^{17}\end{array}$ \\
\hline $\begin{array}{l}\text { Truvada + } \\
\text { Reyataz + } \\
\text { Norvir }\end{array}$ & $\mathrm{TDF} / \mathrm{FTC}+\mathrm{ATV} / \mathrm{r}$ & $78.00 \%$ & $74.00 \%$ & $74.00 \%$ & $74.00 \%$ & $74.00 \%$ & $74.00 \%$ & $74.00 \%$ & $74.00 \%$ & $74.00 \%$ & $74.00 \%$ & $\begin{array}{l}\text { Molina et al, }{ }^{18} \\
\text { Molina et al }\end{array}$ \\
\hline $\begin{array}{l}\text { Truvada + } \\
\text { Viramune }\end{array}$ & TDF/FTC + NVP & $66.80 \%$ & $66.80 \%$ & $66.80 \%$ & $66.80 \%$ & $66.80 \%$ & $66.80 \%$ & $66.80 \%$ & $66.80 \%$ & $66.80 \%$ & $66.80 \%$ & Soriano et $\mathrm{al}^{20}$ \\
\hline $\begin{array}{l}\text { Truvada + } \\
\text { Prezista }+ \\
\text { Norvir }\end{array}$ & $\mathrm{TDF} / \mathrm{FTC}+\mathrm{DRV} / \mathrm{r}$ & $79.00 \%$ & $79.00 \%$ & $79.00 \%$ & $79.00 \%$ & $79.00 \%$ & $79.00 \%$ & $79.00 \%$ & $79.00 \%$ & $79.00 \%$ & $79.00 \%$ & Mills et $\mathrm{a}^{21}$ \\
\hline $\begin{array}{l}\text { Truvada }+ \\
\text { Kaletra }+ \\
\text { Norvir }\end{array}$ & $\mathrm{TDF} / \mathrm{FTC}+\mathrm{LPV} / \mathrm{r}$ & $76.00 \%$ & $68.00 \%$ & $68.00 \%$ & $68.00 \%$ & $68.00 \%$ & $68.00 \%$ & $68.00 \%$ & $68.00 \%$ & $68.00 \%$ & $68.00 \%$ & $\begin{array}{l}\text { Molina et al, }{ }^{19} \\
\text { Molina et } \mathrm{al}^{20}\end{array}$ \\
\hline $\begin{array}{l}\text { Truvada + } \\
\text { Isentress }\end{array}$ & TDF/FTC + RAL & $86.10 \%$ & $81.00 \%$ & $81.00 \%$ & $81.00 \%$ & $81.00 \%$ & $81.00 \%$ & $81.00 \%$ & $81.00 \%$ & $81.00 \%$ & $81.00 \%$ & $\begin{array}{l}\text { Lennox et al, }{ }^{22} \\
\text { Lennox et } \mathrm{al}^{23}\end{array}$ \\
\hline $\begin{array}{l}\text { Viread + } \\
\text { Epivir + } \\
\text { Sustiva }\end{array}$ & $\mathrm{TDF}+3 \mathrm{TC}+\mathrm{EFV}$ & $76.30 \%$ & $72.60 \%$ & $69.70 \%$ & $69.70 \%$ & $69.70 \%$ & $69.70 \%$ & $69.70 \%$ & $69.70 \%$ & $69.70 \%$ & $69.70 \%$ & Gallant et $\mathrm{al}^{24}$ \\
\hline $\begin{array}{l}\text { Kivexa }+ \\
\text { Sustiva }\end{array}$ & $\mathrm{ABC} / 3 \mathrm{TC}+\mathrm{EFV}$ & $59.00 \%$ & $59.00 \%$ & $59.00 \%$ & $59.00 \%$ & $59.00 \%$ & $59.00 \%$ & $59.00 \%$ & $59.00 \%$ & $59.00 \%$ & $59.00 \%$ & Post et $\mathrm{a}^{25}$ \\
\hline $\begin{array}{l}\text { Kivexa + } \\
\text { Reyataz }+ \\
\text { Norvir }\end{array}$ & $\mathrm{ABC} / 3 \mathrm{TC}+\mathrm{ATV} / \mathrm{r}$ & $81.00 \%$ & $81.00 \%$ & $81.00 \%$ & $81.00 \%$ & $81.00 \%$ & $81.00 \%$ & $81.00 \%$ & $81.00 \%$ & $81.00 \%$ & $81.00 \%$ & Squires et $\mathrm{a}^{26}$ \\
\hline $\begin{array}{l}\text { Kivexa + } \\
\text { Kaletra + } \\
\text { Norvir }\end{array}$ & $\mathrm{ABC} / 3 \mathrm{TC}+\mathrm{LPV} / \mathrm{r}$ & $68.00 \%$ & $60.00 \%$ & $60.00 \%$ & $60.00 \%$ & $60.00 \%$ & $60.00 \%$ & $60.00 \%$ & $60.00 \%$ & $60.00 \%$ & $60.00 \%$ & $\begin{array}{l}\text { Smith et } \mathrm{al}{ }^{27} \\
\text { Pulido et } \mathrm{al}^{28}\end{array}$ \\
\hline
\end{tabular}

Note: Response rate refers to HIV RNA $<50$ copies $/ \mathrm{mL}$.

Abbreviations: 3TC, lamivudine; ABC, abacavir; ATV/r, ritonavir-boosted atazanavir; DRV/r, ritonavir-boosted darunavir; EFV, efavirenz; FTC, emtricitabine; LPV/r, ritonavir-boosted lopinavir; NVP, nevirapine; RAL, raltegravir; TDF, tenofovir.

\section{Sensitivity analysis}

The sensitivity analysis verified the impact of a series of variations of the base case with a large influence on the obtained results. ${ }^{9}$ A series of univariate analyses were carried out on some parameters of the simulation model, such as:

Table 4 Utility values associated with the eight health states identified by the CD4-cell count ${ }^{13}$

\begin{tabular}{lll}
\hline CD4-cell count & Viremia (VL) & Utility \\
\hline$>500$ cells $/ \mu \mathrm{L}$ & $<50$ & 0.946 \\
$>500 \mathrm{cells} / \mu \mathrm{L}$ & $\geq 50$ & 0.946 \\
$35 \mathrm{I}-500 \mathrm{cells} / \mu \mathrm{L}$ & $<50$ & 0.933 \\
$35 \mathrm{I}-500 \mathrm{cells} / \mu \mathrm{L}$ & $\geq 50$ & 0.933 \\
$20 \mathrm{I}-350 \mathrm{cells} / \mu \mathrm{L}$ & $<50$ & $0.93 \mathrm{I}$ \\
$20 \mathrm{I}-350 \mathrm{cells} / \mu \mathrm{L}$ & $\geq 50$ & $0.93 \mathrm{I}$ \\
$<200 \mathrm{cells} / \mu \mathrm{L}$ & $<50$ & 0.830 \\
$<200 \mathrm{cells} / \mu \mathrm{L}$ & $\geq 50$ & 0.830 \\
\hline
\end{tabular}

virological response, HIV-associated mortality rate, and the initial distribution of patients based on the CD4-cell count. In particular, the allotment of patients per CD4-cell count was varied based on the evidence of the study by Gallant et al ${ }^{36}$ and simulated for hypothetical seriousness scenarios. Each parameter was varied with respect to its $95 \%$ confidence interval.

\section{Results}

Table 7 shows the average annual cost and the QALYs for a patient with HIV treated with each of the first-line antiretroviral regimens mentioned in the Italian guidelines. The simulation model shows that patients treated with a single tablet regimen (STR) (0.755 QALY/year) have a better quality of life, with a higher number of QALYs than with other therapeutic regimens, followed by tenofovir/ 
Table 5 Average annual costs for each first-line therapeutic regimen $^{35,36}$

\begin{tabular}{ll}
\hline Treatment & $\begin{array}{l}\text { Annual costs } \\
\text { HAART treatment }\end{array}$ \\
\hline TDF/FTC + EFV (single tablet regimen) & $€ 7226$ \\
TDF/FTC + EFV & $€ 7226$ \\
TDF/FTC + ATV/r & $€ 9016$ \\
TDF/FTC + NVP & $€ 6936$ \\
TDF/FTC + DRV/r & $€ 10,167$ \\
TDF/FTC + LPV/r & $€ 9294$ \\
TDF/FTC + RAL & $€ 13156$ \\
TDF + 3TC + EFV & $€ 6711$ \\
ABC/3TC + EFV & $€ 6776$ \\
ABC/3TC + ATV/r & $€ 8566$ \\
ABC/3TC + LPV/r & $€ 8844$ \\
\hline
\end{tabular}

Abbreviations: $3 T C$, lamivudine; $A B C$, abacavir; ATV/r, ritonavir-boosted atazanavir; $D R V / r$, ritonavir-boosted darunavir; EFV, efavirenz; FTC, emtricitabine; LPV/r, ritonavir-boosted lopinavir; NVP, nevirapine; RAL, raltegravir; TDF, tenofovir.

emtricitabine (TDF/FTC) + raltegravir (0.735 QALY/year) and abacavir/lamivudine $(\mathrm{ABC} / 3 \mathrm{TC})+$ atazanavir/ritonavir (0.731 QALY/year). Table 7 shows the mean treatment cost for a patient with HIV based on the first-line antiretroviral regimen received. The TDF $+3 \mathrm{TC}+$ efavirenz $(\mathrm{EFV})$ regimen $(€ 8211)$ reveals a lower mean treatment cost, followed by TDF/FTC + nevirapine with $€ 8231, \mathrm{ABC}+3 \mathrm{TC}+\mathrm{EFV}$ with $€ 8047$, and TDF + FTC + EFV with $€ 8551$. Comparing the above mentioned costs and outcomes in incremental terms (ICER) with the no-treatment strategy, the STR appeared to be the most cost-effective therapeutic choice $(€ 22,017)$, followed by TDF + 3TC + EFV (€24,526), TDF/FTC + nevirapine $(€ 26,416)$, and TDF + FTC + EFV $(€ 26,558)$; the remaining strategies have an ICER value varying from $€ 28,000$ to $€ 41,000$ per QALY.

The sensitivity analysis carried out on the main variables does not highlight significant variations with respect to the base case. For instance, including the discount rate
$(0 \%-5 \%)$ on costs and QALYs determines an increase of the ICER for all therapeutic regimens. On the other hand, it is worth noting that the cost per QALY decreases with the increase of the seriousness of the treated patient's disease (CD4), showing that severe-illness patients can benefit the most (Table 8).

\section{Discussion}

The therapeutic success against HIV is mainly due to the results obtained by scientific research, which allow finding drugs with a powerful antiviral activity. Since 1996, with the discovery of new classes of drugs and molecules which can thwart viral replication on various fronts, and especially with the introduction of combined therapies, the life expectancy and quality of life of people with HIV have enormously improved. Adding new antiretroviral STRs to conventional therapies can help physicians in the choice of the optimal treatment to administer HIV patients. Since STR is not the only available therapeutic alternative, it was deemed necessary to carry out a comparison with other antiretroviral regimens; therefore the analysis considered the regimens recommended, to a varying extent, by the Italian guidelines. The comparison was not limited to considering clinical effectiveness, but it also evaluated treatment costs. In particular, an incremental cost-effectiveness analysis was performed for each regimen, with respect to the no-treatment option, from the point of view of the Italian national health care system ( $\mathrm{SSN})$ and taking into account the national guidelines. ${ }^{9}$ Such comparisons were carried out with the help of a Markov decision model over a 10-year time horizon. The model estimated QALYs as outcomes and direct health costs (drugs, medical examinations, hospitalizations, tests, and so on) as costs; these costs were attributed a value based on prices and rates as of 2010 .

Table 6 Average annual cost per patient and health state expressed in CD4 (excluding HAART cost) ${ }^{33}$

\begin{tabular}{|c|c|c|c|c|}
\hline & AIDS & CD4+ $<200$ & $20 \mathrm{I}<\mathrm{CD} 4+<500$ & CD4+ $>50 \mathrm{I}$ \\
\hline Hospitalization and therapy & $€ 2457$ & $€ 77 \mid$ & $€ 233$ & $€ 43$ \\
\hline Hospitalizations & $€ 2|2|$ & $€ 674$ & $€ 196$ & $€ 39$ \\
\hline Laboratory tests & $€ 149$ & $€ 64$ & $€ 19$ & $€ 3$ \\
\hline Diagnostic procedures & $€ 187$ & $€ 33$ & $€ 19$ & $€ 0$ \\
\hline Day hospital & $€ 6336$ & $€ 2583$ & $€ 2316$ & $€ \mid 886$ \\
\hline Accesses & $€ 6279$ & $€ 2557$ & $€ 2300$ & $€ I 877$ \\
\hline Medical visits & $€ 57$ & $€ 25$ & $€ 15$ & $€ 9$ \\
\hline Specialist examinations & $€ 314$ & $€ 348$ & $€ 319$ & $€ 299$ \\
\hline Laboratory tests (outpatients) & $€ 980$ & $€ 950$ & $€ 937$ & $€ 859$ \\
\hline Diagnostic procedures (outpatients) & $€ 137$ & $€ 80$ & $€ 21$ & $€ 28$ \\
\hline Total cost & $€ 10,225$ & $€ 4732$ & $€ 3827$ & $€ 3115$ \\
\hline
\end{tabular}

Abbreviation: HAART, highly active antiretroviral therapy. 
Table 7 Results: costs, QALYs and ICER of the base case scenario (I0-year horizon)

\begin{tabular}{|c|c|c|c|c|c|c|c|c|}
\hline \multicolumn{2}{|c|}{$\begin{array}{l}\text { Strength and } \\
\text { evidence } \\
\text { Italian GL }\end{array}$} & Treatment & $\begin{array}{l}\text { Mean cost } \\
\text { per patient }\end{array}$ & $\begin{array}{l}\text { Mean QALYs } \\
\text { per patient }\end{array}$ & $\begin{array}{l}\text { Mean cost } \\
\text { per QALYs }\end{array}$ & \multirow[t]{2}{*}{$\begin{array}{l}\text { Delta } \\
\text { cost }\end{array}$} & \multirow[t]{2}{*}{$\begin{array}{l}\text { Delta } \\
\text { QALYs }\end{array}$} & \multirow[t]{2}{*}{$\begin{array}{l}\text { ICER } \\
\text { QALYs }\end{array}$} \\
\hline & & Untreated & $€ 3492$ & 0.525 & $€ 6645$ & & & \\
\hline \multicolumn{2}{|c|}{ Al } & $\begin{array}{l}\text { TDF/FTC + EFV } \\
\text { (single tablet regimen) }\end{array}$ & $€ 8551$ & 0.755 & $€ \mid \mathrm{I}, 323$ & $€ 5059$ & 0.230 & $€ 22,017$ \\
\hline Al & Al & TDF/FTC + EFV & $€ 8551$ & 0.716 & $€ \mid I, 944$ & $€ 5059$ & 0.190 & $€ 26,558$ \\
\hline Al & Al & $\mathrm{TDF} / \mathrm{FTC}+\mathrm{ATV} / \mathrm{r}$ & $€ 9479$ & 0.722 & $€ \mid 3,124$ & $€ 5988$ & 0.197 & $€ 30,412$ \\
\hline Al & $\mathrm{BI}$ & TDF/FTC + NVP & $€ 8231$ & 0.705 & $€ \mid \mathrm{I}, 678$ & $€ 4740$ & 0.179 & $€ 26,416$ \\
\hline Al & $\mathrm{BI}$ & $\mathrm{TDF} / \mathrm{FTC}+\mathrm{DRV} / \mathrm{r}$ & $€ 10,165$ & 0.727 & $€ 13,977$ & $€ 6674$ & 0.202 & $€ 33,061$ \\
\hline Al & $\mathrm{BI}$ & TDF/FTC + LPV/r & $€ 9517$ & 0.715 & $€|3,3| 2$ & $€ 6026$ & 0.190 & $€ 31,793$ \\
\hline Al & $\mathrm{BI}$ & TDF/FTC + RAL & $€ 12,174$ & 0.735 & $€ 16,552$ & $€ 8682$ & 0.210 & $€ 4 I, 328$ \\
\hline BI & $\mathrm{Al}$ & $\mathrm{TDF}+3 \mathrm{TC}+\mathrm{EFV}$ & $€ 8211$ & 0.718 & $€ \mid I, 438$ & $€ 4719$ & 0.192 & $€ 24,526$ \\
\hline $\mathrm{BI}$ & Al & $\mathrm{ABC} / 3 \mathrm{TC}+\mathrm{EFV}$ & $€ 8047$ & 0.689 & $€ \mid I, 682$ & $€ 4555$ & 0.163 & $€ 27,880$ \\
\hline $\mathrm{BI}$ & Al & $\mathrm{ABC} / 3 \mathrm{TC}+\mathrm{ATV} / \mathrm{r}$ & $€ 9276$ & 0.731 & $€ \mid 2,695$ & $€ 5784$ & 0.205 & $€ 28,182$ \\
\hline $\mathrm{BI}$ & $\mathrm{BI}$ & $\mathrm{ABC} / 3 \mathrm{TC}+\mathrm{LPV} / \mathrm{r}$ & $€ 9117$ & 0.699 & $€ \mid 3,047$ & $€ 5626$ & 0.173 & $€ 32,448$ \\
\hline
\end{tabular}

Abbreviations: 3TC, lamivudine; ABC, abacavir; ATV/r, ritonavir-boosted atazanavir; DRV/r, ritonavir-boosted darunavir; EFV, efavirenz; FTC, emtricitabine; GL, guidelines; ICER, incremental cost-effectiveness ratio; LPV/r, ritonavir-boosted lopinavir; NVP, nevirapine; QALY, quality-adjusted life year; RAL, raltegravir; TDF, tenofovir.

The results of the simulation model show that in terms of cost per gained QALY, STR is the most cost-effective treatment strategy, compared with the other therapeutic regimens recommended by the guidelines. All the ICER values of the various regimens considered by the Italian guidelines were lower than the threshold value of $€ 50,000$, commonly accepted at the international level. ${ }^{36}$ This value has the purpose of expressing the willingness of the decision makers to pay in order to obtain additional health units, or the purpose of making new therapies available to citizens. Though no officially established threshold is available for Italy, it is worth noting that recent guidelines by the Italian Health Economics Association ${ }^{9}$ recommend that a threshold of $€ 25,000-40,000$ be adopted. Other acceptable references of cost-effectiveness for the Italian context are $€ 36,500$ and $€ 60,000$ and have been calculated by two different authors. ${ }^{37,38}$

The favorable result of the STR is probably due to literature evidence showing a better adherence of the patients to STR, which determines an increase of the quality of life of patients with HIV. ${ }^{39}$ However, it is now recognized that low adherence to antiretroviral drugs is strictly linked to the therapeutic regimen failure ${ }^{40}$ and consequently to the indicators of the HIV-disease progression, such as virological failure, ${ }^{41}$ insufficient immunologic reconstitution, the clinical progression of the disease, and lastly, death. ${ }^{42,43}$ Adherence to therapy is not only necessary to obtain a therapeutic result in patients starting a treatment, but also to maintain an effective viral suppression in the course of time. ${ }^{44}$

The sensitivity analysis on the main variables confirmed the validity of the base case. It is worth noting, in particular, that the increasing seriousness of the patients' conditions (CD4-cell decrease) improves the incremental cost-effectiveness ratio with respect to the no-treatment strategy for all therapeutic regimens. This result is consistent with the indications of the Italian and international guidelines, suggesting the maximum evidence of outcomes in the treatment of patients with CD4-cell levels lower than 500. ${ }^{9,31}$ Furthermore, the results of this present study are in line with other pharmacoeconomic analyses, in particular with the study of Ravasio ${ }^{30}$ and with the more recent costutility analysis. ${ }^{45,46}$ Also, the sensitivity analysis includes any reduction in price of drugs due to patent expiry. For example, with the assumption of a $3 \mathrm{TC}$ price reduction of $50 \%$ included into the TDF $+3 \mathrm{TC}+\mathrm{EFV}$ regimen, the most cost-effective strategy remains the STR.

This study has a few limitations, the most important of which concerns the quality of data entered into the model; parameters such as efficacy, for example, are based on studies with a limited time-frame and hence may be inadequate for modeling the treatment of a chronic disease for a longer time. Other important limitations regard the transition probabilities, which were lacking in some cases and thus assumed to remain constant over time, and the utilities, which were derived from different literature sources and considered to be acceptable for an Italian population. ${ }^{47}$ These assumptions were necessary to simplify the model or to take account of incomplete data into literature sources.

In addition to these limitations, the final result should be interpreted taking into account some others constraints. One constraint could be the adoption of a long-term simulation model (10 years) to compare the three alternative regimens, which was built on the basis of clinical information (now 


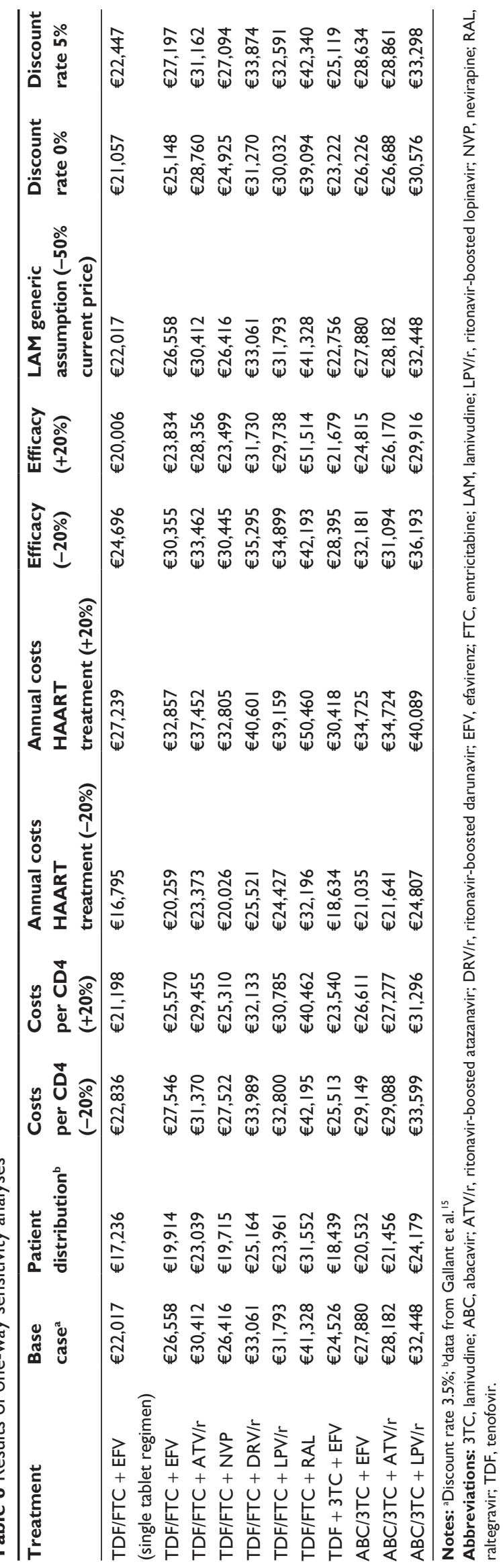

available in the literature) referring to a short-medium period. This is justified by the fact that the evaluation of the benefits and costs of a health program needs synthesis tools capable of giving a representation of the reality to study which is as faithful as possible, ${ }^{30}$ especially when the effects of the program have a time horizon with a long-term impact, or when the data sources are not homogenous (ie, they derive from administrative records, clinical studies, and meta-analyses). It is therefore necessary to use models, such as in the studied case, when the clinical trial (1) is incomplete or lacking (in this case, the necessary data for the economic evaluation derive from different and nonhomogeneous sources) and (2) only measures an intermediate result or a short-period follow-up (the model can be used to predict the possible final results).

It is worth highlighting, however, that the average cost emerging from this present study is substantially in line with a recent analysis of the real treatment costs for HIV patients. ${ }^{48}$ The research work by Rizzardini et al, ${ }^{48}$ developed starting from the administrative database of the reimbursements of the Lombardia region for the years 2004-2007, shows an average annual cost per patient of $€ 9609$. In this present study, the estimated average annual cost per patient is $€ 9270$. However, the difference between the two annual costs $(-4 \%)$ depends on the fact that the average annual cost considered by Rizzardini et al represents patients in the real clinical practice, for instance including patients with hepatitis $\mathrm{C}$ virus infection and previously treated patients, but taking account of all costs during the years 2004 and 2007. With the analysis of naïve patients only, under the same terms used in the present analysis, the results of the two research studies would certainly converge.

To conclude, it is worth noting that the model developed is a dynamic instrument that can be adapted to various health care settings (overall in chronic disease, such as hepatitis $\mathrm{B}$ virus or HIV) in that it can be run using different input data (ie, efficacy, cost, and epidemiological data). ${ }^{49}$ By allowing the simulation of different scenarios, it represents an invaluable tool for policy makers and health care professionals to make short- and long-term cost projections and thus evaluate their impact on the available budgets.

\section{Disclosure}

The study was financially supported by Gilead Sciences Srl, Milan, Italy.

\section{References}

1. World Health Organization (WHO). Global summary of the HIV/AIDS epidemic, 2009. Available from: http://www.who.int/hiv/data/2009 global_summary.png. Accessed September 23, 2011. 
2. National Institute of Health - Istituto Superiore di Sanità (ISS). Notiziario dell'Istituto Superiore di Sanità 2010. ISSN 0394-9303. 2010; 23(4 Suppl 1). [Italian].

3. Steinbrook R. Providing antiretroviral therapy for HIV Infection. NEngl J Med. 2001;344:844-846.

4. Schackman BR, Gebo KA, Walensky RP, et al. The lifetime cost of current human immunodeficiency virus care in the United States. Med Care. 2006;44(11):990-997.

5. Mocroft A, Ledergerber B, Katlama C, et al; for the EuroSIDA study group. Decline in the AIDS and death rates in the EuroSIDA study: an observational study. Lancet. 2003;362:22-29.

6. The Antiretroviral Therapy Cohort Collaboration. Life expectancy of individuals on combination antiretroviral therapy in high-income countries: a collaborative analysis of 14 cohort studies. Lancet. 2008; 372:293-299.

7. Volberding PA, Deeks SG. Antiretroviral therapy and management of HIV infection. Lancet. 2010;376:49-62.

8. Freedberg KA, Losina E, Weinstein MC, et al. The cost effectiveness of combination antiretroviral therapy for HIV disease. $N$ Engl J Med. 2001;344:824-831.

9. Ministry of Health, National Committee on AIDS - Commissione Nazionale per la lotta contro l'AIDS, Linee Guida Italiane sull'utilizzo dei farmaci antiretrovirali e sulla gestione diagnosticoclinica delle persone con infezione da HIV-1, Ministero della Salute, luglio 2010. [Italian].

10. Drummond MF, O'Brien BJ, Stoddart GL, et al. Methods for the economic evaluation of health care programmes. 3rd ed. New York: Oxford University Press; 2006.

11. Italian Health Economics Association - Associazione Italiana di Economia Sanitaria (AIES). Italian Guidelines proposal on how to conduct economic evaluation studies of health programs. Pharmacoeconomics Italian Research Articles; 2009;11:83-93. [Italian].

12. Emilia-Romagna Region, Epidemiologic Survey on HIV/AIDS, Regione Emilia-Romagna, Lo stato dell' 'infezione da HIV/AIDS in emiliaromagna Aggiornamento sull'epidemia e primi risultati del sistema di sorveglianza dell'infezione da HIV al 31/12/2009. [Italian].

13. Simpson KN, Luo MP, Chumney E, et al. Cost-effectiveness of lopinavir/ ritonavir versus nelfinavir as the first-line highly active antiretroviral therapy regimen for HIV infection. HIV Clin Trials. 2004;5:294-304.

14. Pezzotti P, Angeletti C. Public expenditure on antiretroviral drugs: a budget impact analysis model based on regional data - I determinanti della spesa per antiretrovirali: un modello di analisi di budget impact basato su dati regionali Roma, 16 giugno 2010. [Italian].

15. Gallant JE, DeJesus E, Arribas JR, et al; for the Study 934 Group. Tenofovir DF, emtricitabine, and efavirenz vs zidovudine, lamivudine, and efavirenz for HIV. N Engl J Med. 2006;354(3):251-260.

16. Pozniak AL, Gallant JE, DeJesus E, et al. Tenofovir disoproxil fumarate, emtricitabine, and efavirenz versus fixed-dose zidovudine/lamivudine and efavirenz in antiretroviral-naive patients virologic, immunologic, and morphologic changes - a 96-week analysis. J Acquir Immune Defic Syndr. 2006;43:535-540.

17. Arribas JR, Pozniak AL, Gallant JE, et al. Tenofovir disoproxil fumarate, emtricitabine, and efavirenz compared with zidovudine/lamivudine and efavirenz in treatment-naive patients: 144-week analysis. J Acquir Immune Defic Syndr. 2008;47(1):74-78.

18. Molina JM, Andrade-Villanueva J, Echevarria J, et al. Once-daily atazanavir/ritonavir versus twice-daily lopinavir/ritonavir, each in combination with tenofovir and emtricitabine, for management of antiretroviral-naive HIV-1-infected patients: 48 week efficacy and safety results of the CASTLE study. Lancet. 2008;372(9639):646-655.

19. Molina JM, Andrade-Villanueva J, Echevarria J, et al. Once-daily atazanavir/ritonavir compared with twice-daily lopinavir/ritonavir, each in combination with tenofovir and emtricitabine, for management of antiretroviral-naive HIV-1-infected patients: 96-week efficacy and safety results of the CASTLE study. JAcquir Immune Defic Syndr. 2010;53(3): $323-332$.
20. Soriano V, Köppe S, Mingrone H, et al. Prospective comparison of nevirapine and atazanavir/ritonavir both combined with tenofovir DF/ emtricitabine in treatment-naive HIV-1 infected patients: ARTEN study week 48 results. Program and abstracts of the 5th International AIDS Society Conference on HIV Pathogenesis, Treatment and Prevention; July 19-22, 2009; Cape Town, South Africa. Abstract LBPEB07.

21. Mills AM, Nelson M, Jayaweera D, et al. Once-daily darunavir/ritonavir vs lopinavir/ritonavir in treatment-naive, HIV-1-infected patients: 96-week analysis. AIDS. 2009;23(13):1679-1688.

22. Lennox JL, DeJesus E, Lazzarin A, et al. Safety and efficacy of raltegravir-based versus efavirenz-based combination therapy in treatment-naive patients with HIV-1 infection: a multicentre, double-blind randomised controlled trial. Lancet. 2009;374(9692):796-806.

23. Lennox JL, Dejesus E, Berger DS, et al; for the STARTMRK Investigators. Raltegravir versus efavirenz regimens in treatment-naive HIV-1-infected patients: 96-week efficacy, durability, subgroup, safety, and metabolic analyses. J Acquir Immune Defic Syndr. 2010;55(1): $39-48$.

24. Gallant JE, Staszewski S, Pozniak AL, et al; for the 903 Study Group. Efficacy and safety of tenofovir DF vs stavudine in combination therapy in antiretroviral naive patients: a 3-year randomized trial. JAMA. 2004; 292(2):191-201.

25. Post FA, Moyle GJ, Stellbrink HJ, et al. Randomized comparison of renal effects, efficacy, and safety with once-daily abacavir/lamivudine versus tenofovir/emtricitabine, administered with efavirenz, in antiretroviralnaive, HIV-1-infected adults: 48-week results from the ASSERT study. J Acquir Immune Defic Syndr. 2010;55(1):49-57.

26. Squires K, Young B, DeJesus E, et al. Similar efficacy and tolerability of atazanavir (ATV) compared to ATV/ritonavir (RTV, r), each in combination with abacavir/lamivudine $(\mathrm{ABC} / 3 \mathrm{TC})$, after initial suppression with $\mathrm{ABC} / 3 \mathrm{TC}+\mathrm{ATV} / \mathrm{r}$ in HIV-1 infected patients: 84 week results of the ARIES trial. Program and abstracts of the 5th International AIDS Society Conference on HIV Pathogenesis, Treatment and Prevention; July 19-22, 2009; Cape Town, South Africa. Abstract WELBB103.

27. Smith KY, Patel P, Fine D, et al; for the HEAT Study Team. Randomized, double-blind, placebo-matched, multicenter trial of abacavir/lamivudine or tenofovir/emtricitabine with lopinavir/ritonavir for initial HIV treatment. AIDS. 2009;23(12):1547-1556.

28. Pulido F, Estrada V, Baril JG, et al. Long-term efficacy and safety of fosamprenavir plus ritonavir versus lopinavir/ritonavir in combination with abacavir/lamivudine over 144 weeks. HIV Clin Trials. 2009;10(2): $76-87$.

29. EQ-5D [homepage on the Internet]. Rotterdam, The Netherlands: EuroQol Group. Available from: http://www.euroqol.org. Accessed September 23, 2011.

30. Ravasio R. Cost-effectiveness analysis of emtrcitabine/tenofovir disoproxil plus efavirenz vs other antiretroviral regimes in fist line treatment of HIV patient. Giornale Italiano di Health Technology Assessement. 2010;3(1):1-11. [Italian].

31. Gazzard B; for the BHIVA Writing Committee. British HIV Association guidelines for the treatment of HIV-infected adults with antiretroviral therapy. HIV Med. 2006;7:487-503.

32. Italian Medicines Agency - Agenzia Italiana del Farmaco. Negoziazione e rimborsabilità. Available at: http://www.agenziafarmaco.gov.it/it/ content/negoziazione-e-rimborsabilit\%C3\%A0. Accessed September 23, 2011. [Italian].

33. Garattini L, Tediosi F, Di Cintio E, Yin D, Parazzini F; for Gruppo di Studio ARCA (AIDS Resources and Costs Analysis). Resource utilization and hospital cost of HIV/AIDS care in Italy in the era of highly active antiretroviral therapy. AIDS Care. 2001;13(6):733-741.

34. ISTAT, Istituto Nazionale di Statistica. Available at: http://seriestoriche. istat.it/index.php?id=7\&user_100ind_pi1[id_pagina] $=70 \&$ cHash $=468$ e508f3b1982a1c919b740b8f13d66. Accessed on February 1, 2011.

35. So.Re.Sa. SpA - Società Regionale per la Sanità. Pharma Annuario. November 2010. 
36. Jonsson B. Changing health envìronment: the challenge to demonstrate cost-effectiveness of new compounds. Pharmacoeconomics. 2004; 22 Suppl 4:5-10

37. Lucioni C, Ravasio R. How to evaluate the results of a pharmacoeconomic study? Pharmacoeconomics - Italian Research Articles. 2004; 6(3):121-130.

38. Messori A, Santarlasci B, Trippoli S, Vaiani M. Clinical benefit and economic value: methodology and an economic application. Pharmacoeconomics - Italian Research Articles. 2003;5(2):53-67.

39. Airoldi M, Zaccarelli M, Bisi L, et al. One-pill once-a-day HAART: a simplification strategy that improves adherence and quality of life of HIV-infected subjects. Patient Prefer Adherence. 2010;4:115-125.

40. D’Arminio Monforte A, Lepri AC, Rezza G, et al. Insights into the reasons for discontinuation of the first highly active antiretroviral therapy (HAART) regimen in a cohort of antiretroviral naïve patients. ICONA Study Group. Italian Cohort of Antiretroviral-Naïve Patients. AIDS. 2000;14:499-507.

41. Paterson DL, Swindells S, Mohr J, et al. Adherence to protease inhibitor therapy and outcomes in patients with HIV infection. Ann Intern Med. 2000;133:21-30.

42. Bangsberg DR, Perry S, Charlebois ED, et al. Non-adherence to highly active antiretroviral therapy predicts progression to AIDS. AIDS. 2001; 15:1181-1183

43. Lima VD, Harrigan R, Bangsberg DR, et al. The combined effect of modern highly active antiretroviral therapy regimens and adherence on mortality over time. J Acquir Immune Defic Syndr. 2009;50:529-536.
44. Antinori A, Cozzi-Lepri A, Ammassari A, et al. Relative prognostic value of self-reported adherence and plasma NNRTI/PI concentrations to predict virological rebound in patients initially responding to HAART. Antivir Ther. 2004;9:291-296.

45. Moeremans K, Hemmett L, Hjelmgren J, Allegri G, Smets E. Cost effectiveness of darunavir/ritonavir $600 / 100 \mathrm{mg}$ bid in treatmentexperienced, lopinavir-naive, protease inhibitor-resistant, HIV-infected adults in Belgium, Italy, Sweden and the UK. Pharmacoeconomics. 2010;28 Suppl 1:147-167.

46. Moeremans K, Annemans L, Löthgren M, et al. Cost effectiveness of darunavir/ritonavir $600 / 100 \mathrm{mg}$ bid in protease inhibitor-experienced, HIV-1-infected adults in Belgium, Italy, Sweden and the UK. Pharmacoeconomics. 2010;28 Suppl 1:107-128.

47. Simpson KN, Strassburger A, Jones WJ, Dietz B, Rajagopalan R. Comparison of Markov model and discrete-event simulation techniques for HIV. Pharmacoeconomics. 2009;27(2):159-165.

48. Rizzardini G, Restelli U, Bonfanti P, et al. The cost of HIV disease in Northern Italy: the payer's perspective. J Acquir Immune Defic Syndr. 2011;57(3):211-217.

49. Colombo GL, Gaeta GB, Viganò M, Di Matteo S. A cost-effectiveness analysis of different therapies in patients with chronic hepatitis B in Italy. Clinicoecon Outcomes Res. 2011;3:37-46.
ClinicoEconomics and Outcomes Research

\section{Publish your work in this journal}

ClinicoEconomics \& Outcomes Research is an international, peerreviewed open-access journal focusing on Health Technology Assessment, Pharmacoeconomics and Outcomes Research in the areas of diagnosis, medical devices, and clinical, surgical and pharmacological intervention. The economic impact of health policy and health systems

\section{Dovepress}

organization also constitute important areas of coverage. The manuscript management system is completely online and includes a very quick and fair peer-review system, which is all easy to use. Visit http://www.dovepress.com/testimonials.php to read real quotes from published authors. 